\title{
27. GEOCHEMISTRY OF THE STABLE CARBON ISOTOPES IN SOME INDIAN OCEAN SEDIMENTS
}

\author{
John A. Calder, George J. Horvath,' and David J. Shultz, \\ Department of Oceanography, Florida State University, Tallahassee, Florida \\ and \\ Juanita W. Newman, University of Texas, Marine Science Institute, Port Aransas, Texas
}

\section{INTRODUCTION}

The stable isotope ratio of the organic carbon preserved in marine sediments is a useful indicator of the paleoenvironments of an area because it is affected by the relative amounts of terrestrial- and marine-derived organic materials present and by environmental conditions, primarily temperature, prevailing during the growth of the source organisms for the carbon.

Rogers and Koons (1969) suggested that $\mathrm{C}^{13} / \mathrm{C}^{12}$ isotopic ratios in marine sediments are determined by the variations in the surface water temperature at the time of deposition rather than by the variations in the relative amounts of terrestrially and marine-derived organic materials incorporated in the sediments at a given location (Sackett, 1964). According to Sackett and Rankin (1970), in portions of large ocean basins where the terrestrial contributions are negligible, the isotopic composition of sedimentary organic carbon may be related to the isotopic composition of the plankton cells which is in turn controlled by temperature. Rogers et al. (1972) obtained $\delta \mathrm{C}^{13}$ values of organic matter in. Cretaceous, Tertiary, and Quaternary sediments from the North Atlantic, and concluded that surface water temperature is the most significant factor accounting for the observed variations in $\delta \mathrm{C}^{13}$. However, Parker et al. (1972) and Newman et al. (1973) found that the variations in carbon isotope ratios observed in Gulf of Mexico sediments reflected changes in the input of land-derived sediments (and organic matter) which in turn were controlled by climatic shifts during and since the Pleistocene.

According to the current consensus, the terrestrial component plays a major role in controlling $\delta \mathrm{C}^{13}$ of marine sediments, while the effect of surface water temperature is of secondary importance. This assumption guided our preliminary interpretation. It should be noted that some of the $\delta \mathrm{C}^{13}$ values obtained in this study are more negative than would be provided by material which was $100 \%$ terrestrial in origin, suggesting that temperature or some other significant but unknown factors may be controlling carbon isotope ratios in marine sediments.

'Present address: State of Florida, Department of Pollution Control, 2562 Executive Center Circle East, Tallahassee, Florida.
Analytical procedures used for the determination of $\mathrm{C}^{13} /{ }^{12}$ ratios were described by Parker et al. (1972). Analytical precision was $\pm 0.3^{\circ} \%$ or better. All $\delta \mathrm{C}^{13}$ values are reported relative to the standard NBS 20 and have been corrected for mixing, tailing, and $\mathrm{O}^{17}$.

\section{RESULTS}

Site 252 (Table 1 and Figure 1) was located in the Crozet Basin, which has been a deep water environment from the Miocene to the present. Throughout that time, the sediment was deposited below the carbonate compensation depth. Therefore, the contribution of terrestrial organic matter is probably minimal at this site. The $\delta \mathrm{C}^{13}$ values for cores from this site could be interpreted as due either to a cold water marine environment or to an influx of terrestrial carbon. The latter possibility is made unlikely by sedimentological evidence. The shift in $\delta \mathrm{C}^{13}$ at 104-100 meters correlates with the lower Pliocene-upper Pliocene boundary.

TABLE 1

Organic Carbon Content and $\delta \mathrm{C}^{13}$ Values for Site 252

\begin{tabular}{cccc}
\hline Core-Section & $\begin{array}{c}\text { Depth Below } \\
\text { Sea Floor }(\mathrm{m})\end{array}$ & $\begin{array}{c}\% \text { Org. C } \\
\mathrm{CO}_{3}=\text { Free }\end{array}$ & $\delta \mathrm{C}^{13}$ NBS 20 \\
\hline $2-2$ & 1.6 & 0.11 & -24.7 \\
$2-3$ & 4.4 & 0.40 & -24.5 \\
$3-3$ & 48.6 & 0.25 & -25.0 \\
$4-3$ & 99.4 & 0.22 & -25.0 \\
$4-6$ & 103.8 & 0.21 & -25.8 \\
$5-2$ & 147.9 & 0.13 & -26.4 \\
$6-3$ & 193.1 & 0.21 & -26.0 \\
$7-2$ & 239.9 & 0.16 & -25.6 \\
\hline
\end{tabular}

Site 253 (Table 2 and Figure 2), from the Ninetyeast Ridge, penetrated to a volcanic sequence older than Eocene. The volcanic sequence contained carbon with both the most negative and the most positive $\delta \mathrm{C}^{13} \mathrm{val}-$ ues of all the cores reported on here. However, the cause or significance of these extreme numbers cannot be determined at this time. From other evidence, it is known that the volcanic sequence was deposited in shallow water. From the end of the volcanic stage until the end of the Eocene the $\delta \mathrm{C}^{13}$ values $(-26.5$ to -25.5$)$ indicate a continued shallow water environment with significant terrestrial input. The $\delta \mathrm{C}^{13}$ values are more positive in the Oligocene to Miocene sequence ( 92 to 70 $\mathrm{m}$ ) indicating either a deepening trend with decreased 


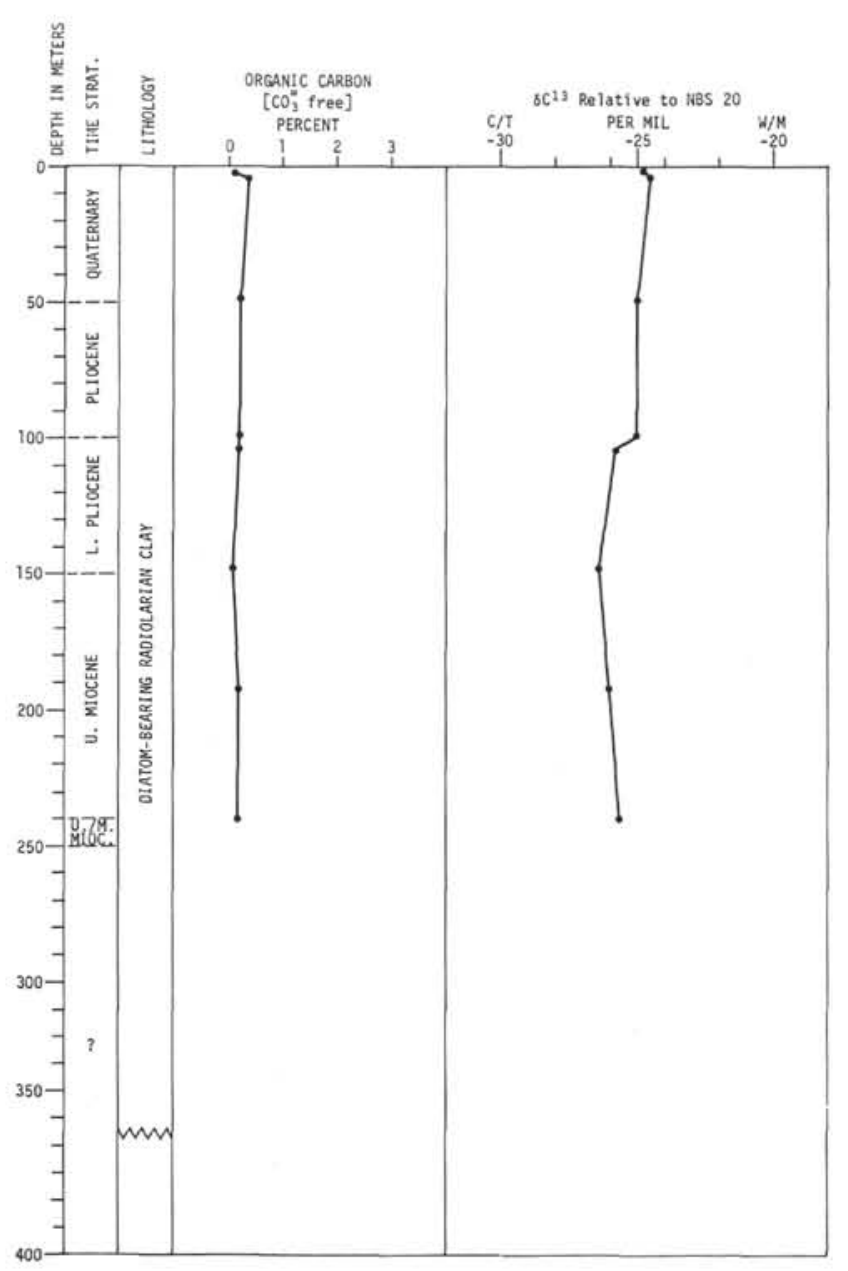

Figure 1. Site 252.

terrestrial input or a warming of the marine waters. On the basis of other evidence we prefer to interpret the change in $\delta \mathrm{C}^{13}$ as reflecting a warming trend. If the temperature dependence of stable carbon isotope fractionation during photosynthesis is taken as $0.2^{\circ} / 00$ to $0.4 \%$ per degree C (Sackett and Rankin, 1970), then the temperature increased from Oligocene to Miocene by $8^{\circ}$ to $16^{\circ} \mathrm{C}$. From the Miocene to the present, the $\delta \mathrm{C}^{13}$ values again became more negative, probably as a result of a cooling trend.

At Site 254 (Table 3 and Figure 3), also from Ninetyeast Ridge, the $\delta \mathrm{C}^{13}$ values indicate a significant terrestrial input in the section between 266 and 210 meters. The paleoecology of this section shows a mollusk assemblage characteristic of a tropical shallow water marine environment (P. Jung, personal communication) and interpretation of pollen and spore remains leads to the same conclusion (Kemp, Chapter 34, this volume). Kemp postulates a lagoonal situation with mangrove swamp-like vegetation. It is interesting to note that the organic matter in present-day-mangrove swamps in the Florida Everglades have $\delta \mathrm{C}^{13}$ values almost identical with those found in this section (J. A. Calder, unpublished data). Above 210 meters
TABLE 2

Organic Carbon Content and $\delta \mathrm{C}^{13}$ Values for Site 253

\begin{tabular}{|c|c|c|c|}
\hline Core-Section & $\begin{array}{l}\text { Depth Below } \\
\text { Sea Floor }(\mathrm{m})\end{array}$ & $\begin{array}{l}\% \text { Org. C. } \\
\mathrm{CO}_{3}=\text { Free }\end{array}$ & $\delta C^{13}$ NBS 20 \\
\hline $1-1$ & 0.8 & - & -25.3 \\
\hline $6-2$ & 49.4 & - & -24.0 \\
\hline $7-3$ & 60.0 & 0.98 & -23.6 \\
\hline $8-2$ & 68.9 & 0.45 & -22.5 \\
\hline $8-6$ & 74.5 & 0.25 & -23.4 \\
\hline $10-6$ & 93.4 & 0.32 & -24.6 \\
\hline $11-3$ & 98.2 & 0.26 & -25.7 \\
\hline $11-5$ & 101.4 & 0.32 & -25.8 \\
\hline $12-3$ & 108.1 & 0.33 & -26.2 \\
\hline $13-1$ & 114.4 & 0.32 & -26.7 \\
\hline $13-3$ & 117.4 & 0.42 & -26.7 \\
\hline $14-3$ & 127.0 & 0.23 & -26.4 \\
\hline $16-3$ & 145.2 & 0.27 & -26.6 \\
\hline $16-6$ & 150.8 & 0.26 & -26.6 \\
\hline $17-2$ & 153.6 & 0.04 & -28.8 \\
\hline $18-2$ & 163.9 & 0.28 & -27.9 \\
\hline $18-4$ & 165.6 & 0.19 & -28.5 \\
\hline $20-1$ & 181.4 & 0.44 & -28.6 \\
\hline $21-2$ & 191.6 & 0.05 & -29.6 \\
\hline $25-2$ & 230.0 & 0.12 & -28.0 \\
\hline $30-1$ & 270.5 & 0.16 & -28.0 \\
\hline $31-2$ & 281.8 & 0.06 & -31.0 \\
\hline $36-1$ & 327.5 & 0.07 & -29.5 \\
\hline $38-1$ & 346.4 & 0.08 & -29.1 \\
\hline $40-2$ & 366.4 & 0.08 & -27.3 \\
\hline $41-1$ & 374.7 & 0.06 & $-14.9^{a}$ \\
\hline $42-2$ & 386.3 & 0.05 & -28.3 \\
\hline $43-2$ & 394.5 & 0.13 & $-21.6^{a}$ \\
\hline $45-5$ & 419.0 & 0.17 & -27.0 \\
\hline $47-2$ & 433.3 & 0.05 & -28.0 \\
\hline $49-2$ & 452.1 & 0.03 & $-33.5 a$ \\
\hline $55-2$ & 509.8 & 0.24 & -27.6 \\
\hline $57-2$ & 547.2 & 0.09 & -27.2 \\
\hline
\end{tabular}

${ }^{\mathrm{a}}$ These extreme values may be anomalous. They are plotted with dashed lines in Figure 2.

(Oligocene), the percentage of organic carbon decreases, and the $\delta \mathrm{C}^{13}$ shifts to values typical for a temperate to tropical open-marine environment. This characteristic continues until 60 meters (mid-Miocene). Above 60 meters the environment of deposition became progressively cooler.

Both Sites 256 and 257 were in the Wharton Basin. Sedimentologic study indicates a high content of detrital clay in samples from both sites. At Site 256 the detrital character extends throughout the length of the hole. The $\delta \mathrm{C}^{13}$ values (Table 4 and Figure 4 ) are consistent with a very high terrestrial content. At Site 257 the $\delta C^{13}$ values (Table 5 and Figure 5) are more positive, indicating a greater pelagic contribution to the organic matter, even though Site 257 is closer to existing land masses. This could mean that Site 256 was downslope from Site 257 and collected a greater terrestrial input due to gravity and current regimes, or Site 257 was subjected to greater scouring activity subsequent to deposition of terrestrial material.

At Site 258 the $\delta C^{13}$ values (Tables 6 and 7 and Figure 6) are closely correlated with sediment type. The pelagic ooze sequence from 0 to 90 meters has $\delta \mathrm{C}^{13}$ values from -20 to -22 . The chalk and siliceous limestone sequence 


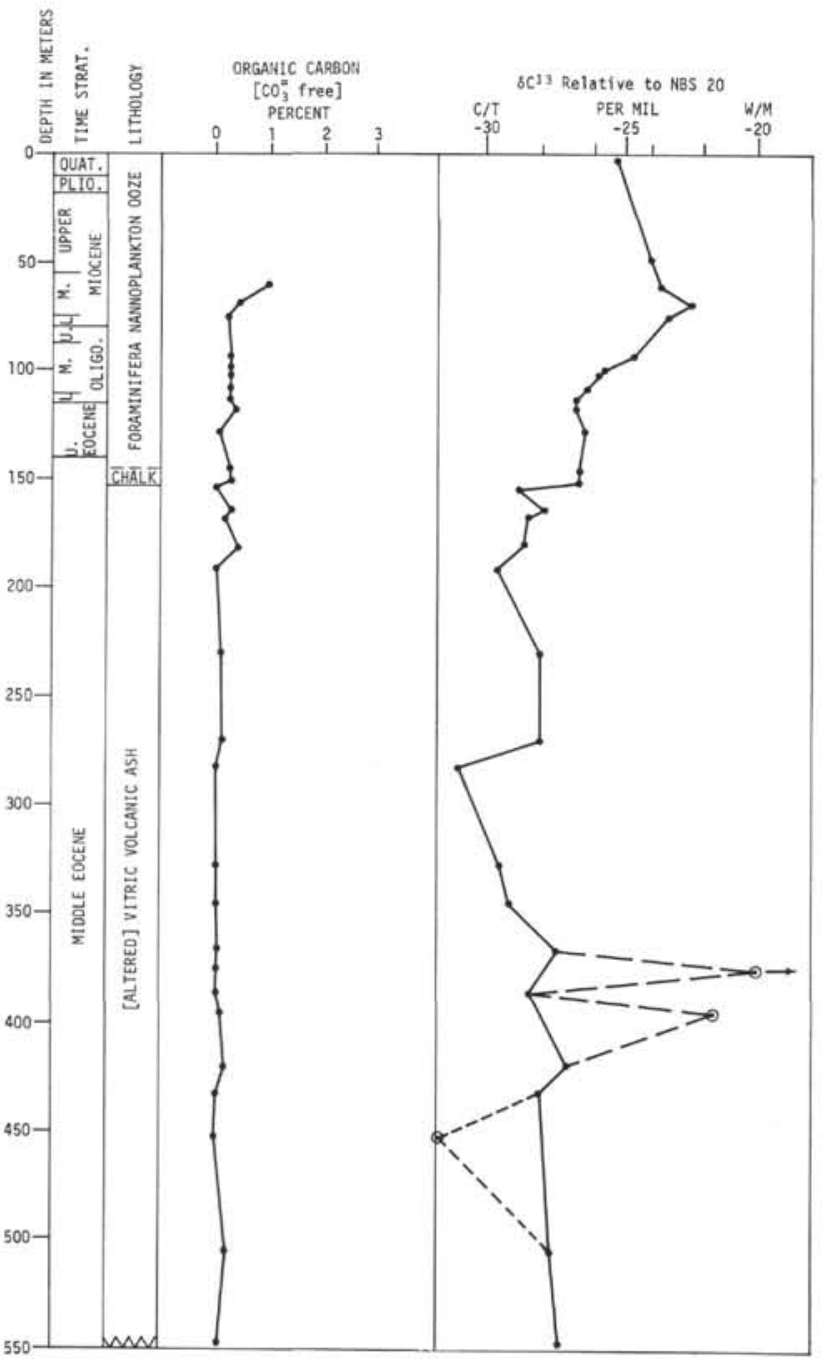

Figure 2. Site 253.

TABLE 3

Organic Carbon Content and $\delta \mathrm{C}^{13}$ Values for Site 254

\begin{tabular}{cccc}
\hline Core-Section & $\begin{array}{c}\text { Depth Below } \\
\text { Sea Floor }(\mathrm{m})\end{array}$ & $\begin{array}{r}\% \text { Org. C } \\
\mathrm{CO}_{3}=\text { Free }\end{array}$ & $\delta C^{13}$ NBS 20 \\
\hline $3-5$ & 22.4 & - & -23.7 \\
$5-2$ & 35.6 & - & -22.3 \\
$7-5$ & 59.9 & - & -19.4 \\
$8-6$ & 70.3 & - & -20.4 \\
$11-6$ & 99.7 & 0.34 & -20.5 \\
$18-5$ & 154.8 & 0.29 & -21.7 \\
$20-6$ & 175.8 & 0.25 & -21.9 \\
$24-1$ & 210.4 & 0.86 & -23.8 \\
$25-1$ & 219.8 & 1.29 & -23.5 \\
$27-3$ & 242.5 & 1.05 & -24.8 \\
$30-1$ & 267.6 & 0.11 & -27.6 \\
\hline
\end{tabular}

from 126 to 202 meters has $\delta \mathrm{C}^{13}$ values from -24 to -24.5 . The micarb chalk sequence from 236 to 256 meters has a $\delta \mathrm{C}^{13}$ value of -26 . The shift to more positive values at 263 meters correlates with the ferruginous clay sequence, which was deposited in deeper waters. The

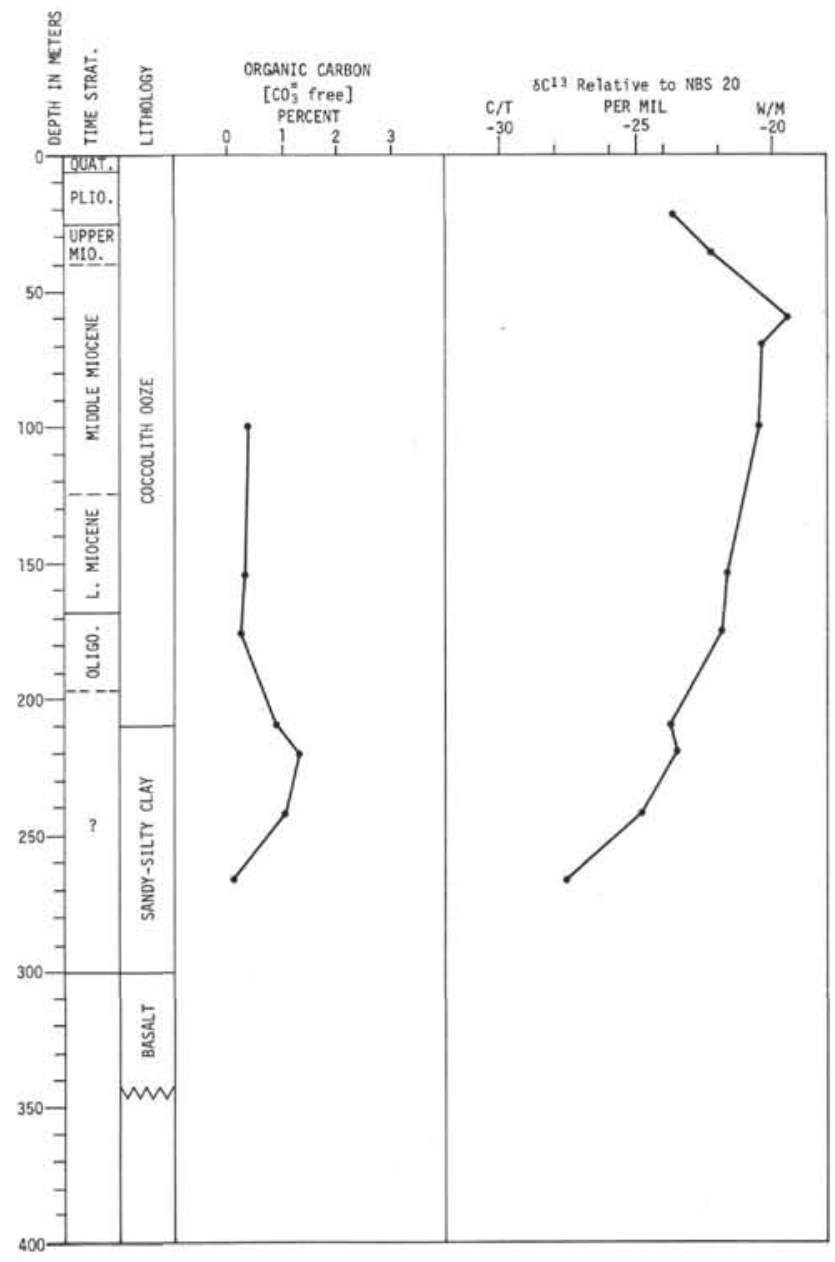

Figure 3. Site 254.

TABLE 4

Organic Carbon Content and $\delta C^{13}$ Values for Site 256

\begin{tabular}{cccc}
\hline Core-Section & $\begin{array}{c}\text { Depth Below } \\
\text { Sea Floor (m) }\end{array}$ & $\begin{array}{c}\% \text { Org. C } \\
\mathrm{CO}_{3}=\text { Free }\end{array}$ & $\delta \mathrm{C}^{13}$ NBS 20 \\
\hline $1-2$ & 1.8 & 0.15 & -28.0 \\
$1-6$ & 8.4 & 0.09 & -25.5 \\
$2-6$ & 17.1 & 0.06 & -28.9 \\
$3-5$ & 53.8 & 0.03 & -25.1 \\
$4-6$ & 94.3 & 0.05 & -24.4 \\
$5-1$ & 125.0 & 0.04 & -24.8 \\
$5-4$ & 129.2 & 0.04 & -25.0 \\
$6-6$ & 189.4 & 0.05 & -24.1 \\
$8-3$ & 241.6 & 0.04 & -23.3 \\
$8-5$ & 244.6 & 0.04 & -23.6 \\
\hline
\end{tabular}

ferruginous sequence has a very high organic carbon content. If this organic material was scavenged (coprecipitated) from the water column without isotope fractionation, the $\delta \mathrm{C}^{13}$ values of this material may be an indirect measure of the $\delta \mathrm{C}^{13}$ of the average dissolved organic carbon (DOC) in the water column during this time (Cretaceous). If this is so, the marine DOC in the Cretaceous was slightly more negative than today's average DOC $\left(-24^{\circ} / 00\right.$ vs $-21^{\circ} \%$ ) . Since the $\delta \mathrm{C}^{13}$ of DOC is the result of a complex and long-term series of events, 


\section{J. A. CALDER ET AL.}

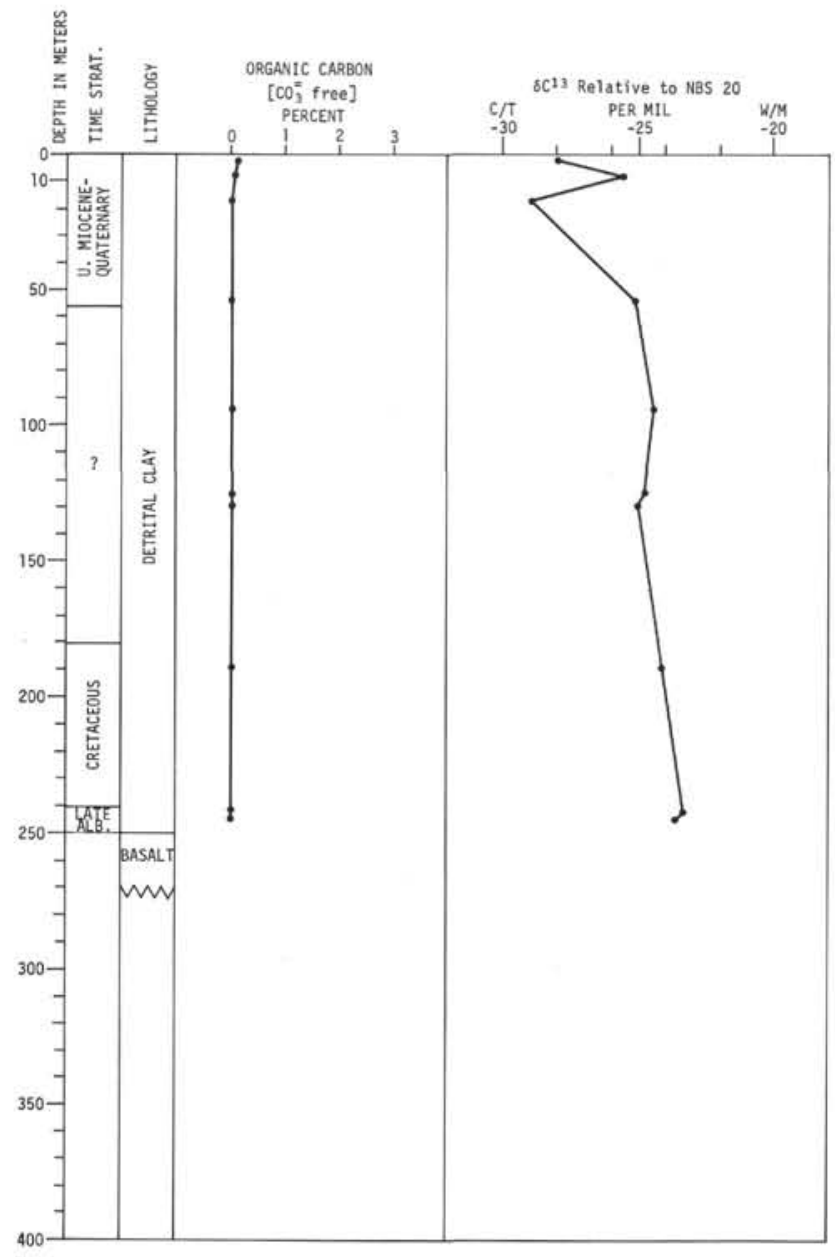

Figure 4. Site 256.

TABLE 5

Organic Carbon Content and $\delta \mathrm{C}^{13}$ Values for Site 257

\begin{tabular}{cccc}
\hline Core-Section & $\begin{array}{c}\text { Depth Below } \\
\text { Sea Floor }(\mathrm{m})\end{array}$ & $\begin{array}{c}\% \text { Org. C } \\
\mathrm{CO}_{3}=\text { Free }\end{array}$ & $\delta C^{13}$ NBS 20 \\
\hline $1-1$ & 0.1 & 0.55 & -26.4 \\
$1-5$ & 7.4 & 0.14 & -24.9 \\
$2-4$ & 14.9 & 0.09 & -23.6 \\
$3-2$ & 49.9 & 0.05 & -23.3 \\
$4-4$ & 90.3 & 0.03 & -23.2 \\
$4-4$ & 90.3 & 1.8 & $-20.6 \mathrm{a}$ \\
$5-2$ & 126.0 & 0.05 & -23.8 \\
$6-1$ & 162.9 & 0.08 & -24.0 \\
$7-2$ & 201.0 & 0.10 & -22.4 \\
$7-5$ & 206.4 & 0.14 & -22.4 \\
$8-2$ & 239.7 & 0.02 & -22.5 \\
$15-1$ & 298.2 & 0.05 & -28.0 \\
\hline
\end{tabular}

${ }^{\mathrm{a}}$ Black inclusions.

mostly biological, there may have been a fundamental change in some aspect(s) of the biological carbon cycle following the Cretaceous.

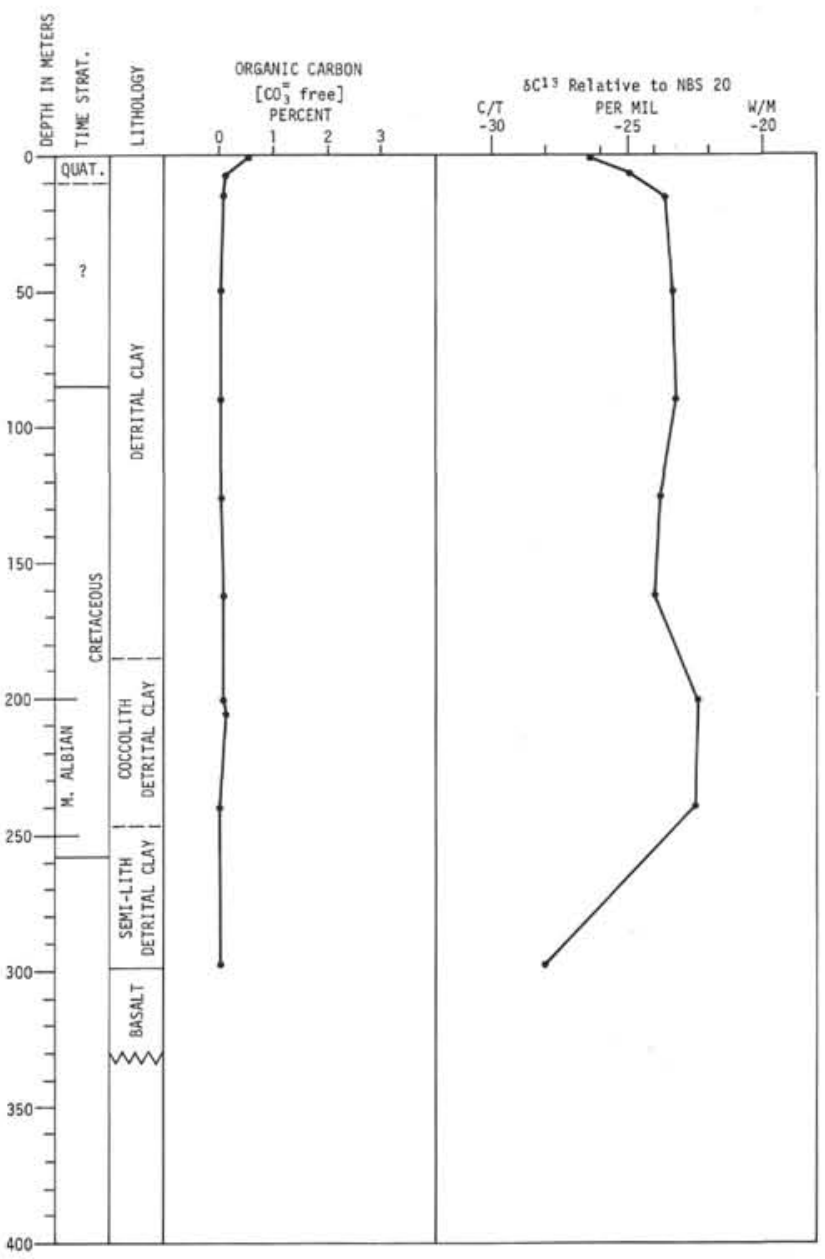

Figure 5. Site 257.

TABLE 6

Organic Carbon Content and $\delta \mathrm{C}^{13}$ Values for Hole 258

\begin{tabular}{cccc}
\hline Core-Section & $\begin{array}{c}\text { Depth Below } \\
\text { Sea Floor }(\mathrm{m})\end{array}$ & $\begin{array}{c}\text { \% Org. C } \\
\mathrm{CO}_{3}=\text { Free }\end{array}$ & $\delta \mathrm{C}^{13}$ NBS 20 \\
\hline $1-2$ & 1.9 & 1.62 & -20.4 \\
$1-5$ & 6.5 & 1.06 & -20.2 \\
$2-3$ & 13.8 & 0.61 & -20.2 \\
$3-1$ & 48.8 & 0.58 & -21.6 \\
$3-6$ & 56.2 & 0.71 & -22.2 \\
$4-1$ & 86.7 & 0.22 & -20.7 \\
$5-2$ & 126.3 & 0.27 & -23.9 \\
$6-5$ & 149.5 & 0.49 & -24.2 \\
$7-2$ & 154.9 & 0.44 & -24.2 \\
$10-2$ & 201.5 & 0.43 & -24.6 \\
$12-2$ & 236.8 & 0.19 & -25.9 \\
$13-2$ & 255.5 & 0.08 & -26.0 \\
$14-1$ & 263.3 & 0.10 & -23.1 \\
$15-2$ & 284.6 & 0.79 & -23.8 \\
$15-5$ & 289.3 & 1.21 & -24.3 \\
$16-2$ & 303.8 & 1.21 & -24.4 \\
$17-2$ & 322.8 & 1.31 & -24.0 \\
$18-3$ & 343.3 & 1.57 & -24.4 \\
$21-3$ & 409.8 & 1.52 & -23.9 \\
$22-5$ & 442.1 & 3.11 & -23.9 \\
$23-2$ & 474.8 & 2.10 & -23.6 \\
$24-2$ & 512.1 & 1.41 & -23.5 \\
$24-5$ & 517.4 & 0.52 & -23.5 \\
$25-4$ & 524.3 & 0.45 & -24.4 \\
& & & \\
& & & \\
& & &
\end{tabular}




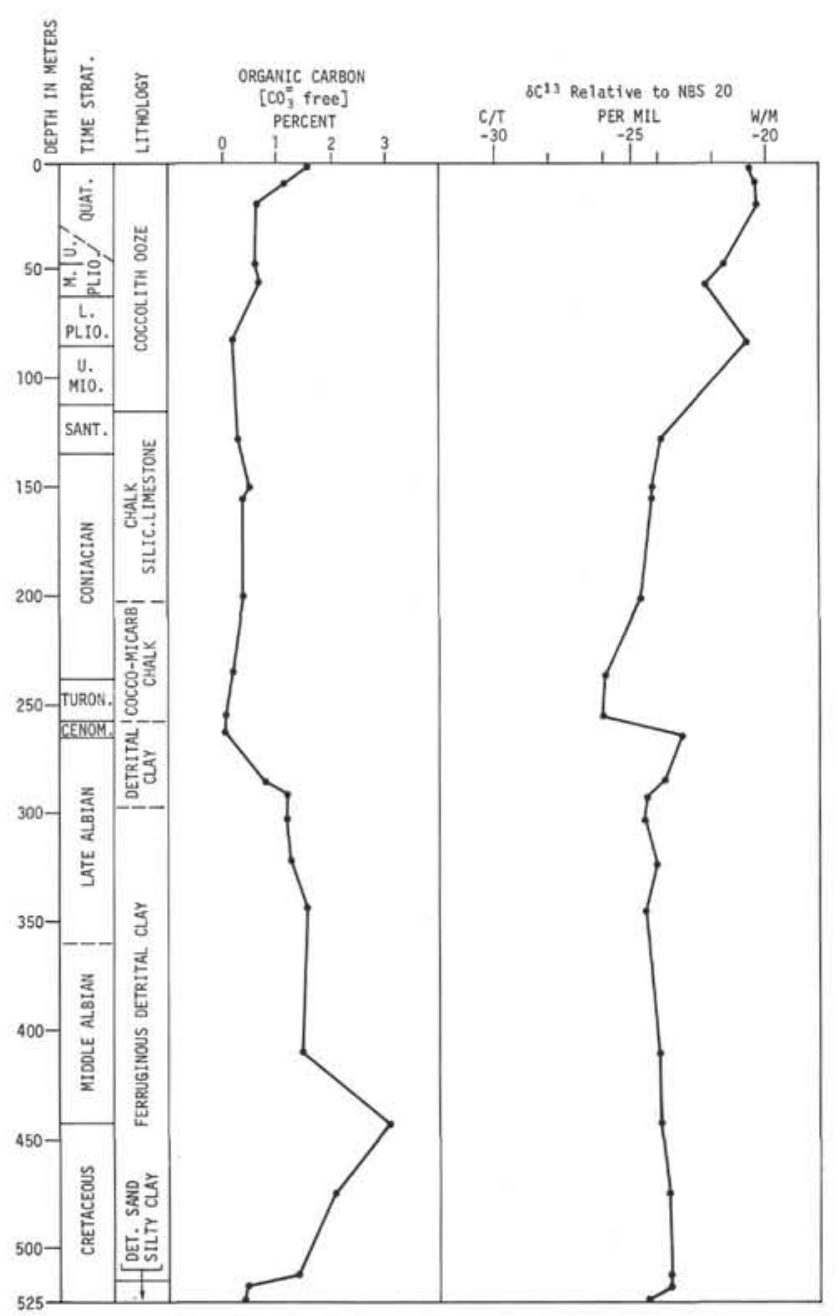

Figure 6. Site 258.

TABLE 7

Organic Carbon Content and $\delta \mathrm{C}^{13}$ Values for Hole 258A

\begin{tabular}{cccc}
\hline Core-Section & $\begin{array}{c}\text { Depth Below } \\
\text { Sea Floor }(\mathrm{m})\end{array}$ & $\begin{array}{c}\% \text { Org. C } \\
\mathrm{CO}_{3}=\text { Free }\end{array}$ & $\delta \mathrm{C}^{13}$ NBS 20 \\
\hline $3-2$ & 31.3 & 0.55 & -22.8 \\
$4-2$ & 40.2 & 0.65 & -20.8 \\
$5-5$ & 54.8 & 0.48 & -21.9 \\
$6-5$ & 73.6 & 0.51 & -22.0 \\
$7-3$ & 99.3 & 0.28 & -21.0 \\
$8-5$ & 111.4 & 0.36 & -21.0 \\
$9-2$ & 116.5 & 0.19 & -23.4 \\
\hline
\end{tabular}

\section{SUMMARY AND CONCLUSIONS}

1. The $\delta \mathrm{C}^{13}$ of the organic matter in these Indian Ocean sediments is strongly influenced by environment of deposition as indicated by frequent correlation between age boundaries and/or sedimentology, and abrupt shifts in $\delta \mathrm{C}^{13}$ values. Both temperature and the amount of terrestrial organic matter significantly influence $\delta \mathrm{C}^{13}$ values.

2. The $\delta \mathrm{C}^{13}$ values of the organic matter from the volcanic ash sequence at Site 253 vary over a $19 \%$ range. It is not possible to interpret this extreme variation at this time.

3. A warming trend began in the Oligocene and lasted until the middle Miocene when a cooling trend began. This temperature fluctuation is the apparent cause for the $\delta \mathrm{C}^{13}$ maxima at 70 meters at Site 253 and at 60 meters at Site 254 . The $\delta \mathrm{C}^{13}$ maxima would correspond to the temperature maxima.

4. Sediments from the Wharton Basin (Sites 256 and 257 ) contain a high content of terrestrial organic matter, while sediments from Ninetyeast Ridge (Sites 253 and 254 ) contain organic material which is primarily pelagic in origin.

5. The geochemistry of the stable carbon isotopes, when taken with other paleoecological data, can provide significant information on ancient environments. However, more detailed sampling of older sediments coupled with more work on recent materials will be required to fully exploit the usefulness of this parameter.

\section{ACKNOWLEDGMENTS}

We thank Drs. Patrick Parker and Sam Savin for their critical reading of this manuscript, and Kathryn Hamilton for her excellent technical assistance. This research was supported in part by NSF Grant GA-24235.

\section{REFERENCES}

Newman, J. W., Parker, P. L., and Behrens, E. W., 1973. Organic carbon isotope ratios in Quaternary cores from the Gulf of Mexico: Geochim. Cosmochim. Acta, v. 37, p. 225238.

Parker, P. L., Behrens, E. W., Calder, J. A., and Shultz, D. J., 1972. Stable carbon isotope ratio variations in the organic carbon from Gulf of Mexico sediments: Contrib. Mar. Sci., Univ. Texas, v. 16, p. 139-147.

Rogers, M. A. and Koons, C. B., 1969. Organic carbon $\delta C^{13}$ values from Quaternary marine sequences in the Gulf of Mexico: A reflection of paleotemperature changes: Trans. Gulf Coast Assoc. Geol. Soc., v. 19, p. 529-534.

Rogers, M. A., van Hinte, J. E., and Sugden, J. G., 1972. Organic carbon $\delta \mathrm{C}^{13}$ values from Cretaceous, Tertiary, and Quaternary marine sequences in the North Atlantic. In Laughton, A. S., Berggren, W. A., et al., Initial Reports of the Deep Sea Drilling Project, Volume 12: Washington (U.S. Government Printing Office), p. 1115-1126.

Sackett, W. M., 1964. The depositional history and isotope composition of marine sediments: Marine Geol., v. 2, p. 173.

Sackett, W. M. and Rankin, J. G., 1970. Paleotemperatures for the Gulf of Mexico: J. Geophys. Res., v. 75, p. 4557. 